\title{
THE CHANGING STATUS OF THE MANDATA PRINCIPIS
}

In the first chapter of his Institutes, Gaius enumerates the institutions that have the competence to create laws for the Romans, iura populi Romani. In addition to the people (leges), the plebs (plebi scita), the senate (senatusconsulta), the magistrates who possess the ius edicendi (magistratuum edicta) and the jurisconsults (responsa prudentium), he mentions the Emperors (principum placita). ${ }^{1}$ The laws issued by the Emperor are not the outcome of a united decision - the people, the plebs, the senate - but are made by him alone. They are called constitutiones. The legal competence of the Emperor was not yet self-evident in Gaius' time (AD 180). Gaius takes the trouble to defend the legal competence of the Emperor by emphasizing it - nec umquam dubitatum est.$-^{2}$ Three types of constitutions are mentioned: the Emperor could create law in the form of a sentence (decretum), an edict (edictum) or a letter (epistula). ${ }^{3}$ The same enumeration can be found in the Institutes of Justinian (AD 533). There is no doubt now any more about the lawgiving capacity of the Emperor, the people having conferred on him all their authority and power by means of the 'royal' law, lex regia, which was passed concerning his office and authority. Consequently the text of the Institutes says: 'whatever the Emperor settled by letter, or decided in his judicial capacity, or ordained by edict, was clearly a statute: and these are what are called constitutions' ${ }^{4}$ Of these constitutions, the letter is the most common and most used form of imperial legislation. Although the Latin Institutes do not give any detailed information about the letter, the Greek Paraphrase by Theophilus does:

And what is an epistula (letter)? It is a written reply by the Emperor in answer to a reference from a magistrate on some doubtful matter. For instance, it happened in some province that,

1 Gaius 1,2: Constant autem iura populi Romani ex legibus, plebiscitis, senatus consultis, constitutionibus principum, edictis eorum, qui ius edicendi habent, responsis prudentium. Inst. 1,2,3: Scriptum ius est lex, pebi scita, senatus consulta, principum placita, magistratuum edicta, responsa prudentium.

2 Gaius 1,5.

3 Gaius 1, 5: Constitutio principis est quod imperator decreto vel edicto vel epistula constituit.

4 Inst. Just. 1,2,6: Quodcumque igitur imperator per epistulam constituit, vel cognoscens decrevit, vel edicto praecepit, legem esse constat: haec sunt quae constitutiones appellantur. Cf. N. van der Wal, 'Die Textfassung der spätrömischen Kaisergesetze in den Codices', BIDR 83 (1980), 1-27. 
on the death of a man, two people disputed his inheritance, a brother and a paternal uncle. Each of them claimed to be the sole person entitled to take the inheritance, the one as brother, the other as paternal uncle. There being no law to decide this doubtful point, the Governor of the province referred it to the Emperor. And the Emperor, having considered the case referred, wrote in reply that the brother was preferred. ${ }^{5}$

A letter started with the name of the Emperor or the Emperors and ended with the date and place of issue. Either the letter was a written response to a petition, precatio, by a private person who is named by his proper name, Hermeti, Callisto, Trophimae, etc., or by his professional status, militi, veterano, liberto, evocato, often with the addition et aliis, et ceteris. Or the letter was, as Theophilus explains, a reaction to a report, relatio, a suggestion, suggestio, or a consultation, consultatio, by a high magistrate, often the praefectus praetorio (per Orientem). ${ }^{6}$ Because the letter was always a written response to a question, the common name for the epistula is rescriptum. ${ }^{7}$

When referring to the epistula as a legal source, Ulpian makes an addition in his textbook: he writes epistula et subscriptio. ${ }^{8}$ Subscription is literally the writing of an answer by the Emperor at the end of the petition. An example can be found in Inst. 2,12pr. in which soldiers alieni iuris are permitted to draw up a testament regarding their peculium castrense. This was initially allowed only for soldiers on active duty, by the authority of the Emperors Augustus and Nerva, and of the illustrious Emperor Trajan; later it was extended by a

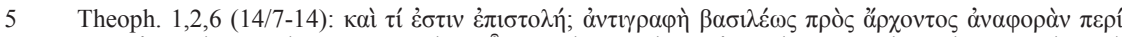

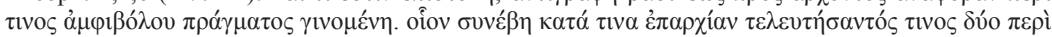

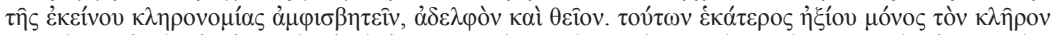

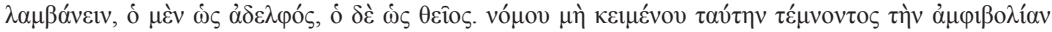

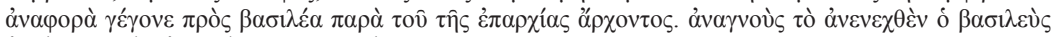

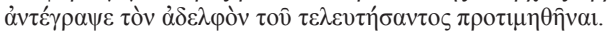

6 C. 1,14,2: Quae ex relationibus vel suggestionibus iudicantium per consultationem in commune ... auditorium... Cf. C. 7,61 and C. 7,62, especially C. 7,62,34.

7 The question raised by a magistrate could also be initiated by the Emperor himself. Cf. J.H.A. Lokin, 'The first constitution of the Codex Justinianus. Some remarks about the imperial legal sources in the Codices Justiniani', SG IX (2014), 343-382 (372-376).

8 D. 1,4,1,1: Ulpianus libro primo institutionum. Quodcumque igitur imperator per epistulam et subscriptionem statuit vel cognoscens decrevit vel de plano interlocutus est vel edicto praecepit, legem esse constat. haec sunt quas volgo constitutiones appellamus. Accordingly, whatever the Emperor had laid down in a letter with his signature, or had decreed on judicial investigation, or had pronounced out of court, or enacted by an edict, amounted beyond question to a statute. The above are cases of what are commonly called 'constitutions'. 


\section{CHANGING STATUS OF THE MANDATA PRINCIPIS}

subscriptio by the Emperor Hadrian to veterans, that is soldiers who had received their discharge. ${ }^{9}$

One category of rules is left out of the enumeration of legal sources, although the precepts clearly stem from the Emperor: the mandata principis, usually translated as 'imperial Instructions'. ${ }^{10}$ They were given to provincial governors before they set out to fulfil their duties.

\section{The Principate}

The history of the mandates is divided into two periods. The first period is called the Principate and runs from Augustus to Diocletian. ${ }^{11}$ It is the period in which Augustus regarded himself, and was regarded, as princeps senatus, i.e. the foremost of the senators. ${ }^{12}$ The expression mandata principis dates from this period and remained unchanged, mandata always in the plural in order to distinguish it from the privat contract of mandatum, and the word principis indicating the time of its origin, that is the period in which the legal competence of the Emperor was not yet self-evident. ${ }^{13}$ According to Dio Cassius, Augustus

Inst. 2,12pr.: Quod quidem initio tantum militantibus datum est tam ex auctoritate divi Augusti quam Nervae nec non optimi imperatoris Traiani, postea vero subscriptione divi Hadriani etiam dimissis militia, id est veteranis, concessum est. The Emperor Gordian confirmed this law in answer to a request by Gallus miles: C. 12,36,4pr. (sine die). Cf. C. 7,43,1: ... propter subcriptionem patris mei.

10 Much has been written about the mandata principis or principum. Every textbook on Roman Law contains a chapter about the mandata. Recently: W. Eck, 'The Emperor, the Law and Imperial Administration', in P.J. du Plessis / C. Ando / K. Tuori (eds.), The Oxford Handbook of Roman Law and Society, Oxford 2016, 98-110 (107-108). In particular: H. Kreller, PWRE 14,1 (1928), s.v. Mandatum; M.I. Finkelstein = M.I. Finley, 'Mandata principum', TRG 13/1 (1934), 150-169 [Finkelstein changed his name to Finley; cf. M. de Sanctis, 'Moses I. Finley. Note per una biografia intellettuale', Quaderni di Storia 10 (1979), 3-37]; A. Dell'Oro, Mandata e Litterae: Contributo allo studio degli atti giuridici del princeps, Bologna 1960; V. Marotta, Multa de iure sanxit. Aspetti della politica del diritto di Antonino Pio, Milano 1988; V. Marotta, Mandata principum, Torino 1991; S. Puliatti, 'La "carta dei doveri". La Novella 17 di Giustiniano e il ripristino dei mandata imperiali', in Studi in onore di Remo Martini, Vol. III, Milano 2009, 253-272.

11 With literature: J.-P. Coriat, Le prince législateur. La technique législative des Sévères et les méthodes de création du droit impérial à la fin du Principat, (Bibliothèque des Écoles françaises d' Athènes et de Rome, 294), Rome 1997, 74-77.

12 Cf. D. Kienast, Augustus: Prinzeps und Monarch, Darmstadt 199933; J. Bleicken, Augustus: Eine Biographie, Berlin 1998.

13 The Senate also issued mandata destined for the governors of the senatorial provinces. See R.J.A. Talbert, The Senate of Imperial Rome, Princeton 1984, 402ff.; Marotta, Mandata principum (note 10 above), $87 \mathrm{ff}$. 
established the practice of issuing mandata in the year in which he assumed the title princeps. ${ }^{14}$ Even after the Principate, the expression mandata principis was maintained, sometimes being extended to mandata principum. It never changed into, for example, mandata Augusti or Augustorum. Only once does an inscription from Pergamon have the words

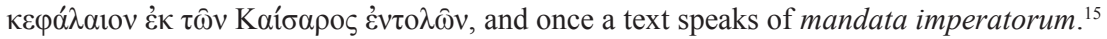
The few texts that have come down to us in the Digest are for the most part found in the first book in the titles concerning the different provincial offices, and in the libri terribiles dealing with criminal law. Nearly all the texts stem from the period of the Severi, ${ }^{16}$ with the exception of one earlier and one later text. ${ }^{17}$ The words most used are mandatis cavetur or continetur ${ }^{18}$ In the mandata the familiar, even intimate, language of the Emperor stands out. In three of the five fragments giving literal quotations of the mandata, the Emperor speaks to his anonymous official in the second person singular: Praeterea debebis custodire ... (D. 47,11,6pr.); ... vinciri iubebis et his, qui solverint, multam dices. (D. 48,3,10); ... vinctos eos custodies et mihi scribes et adicies, quid quisque commiserit (D. 48,19,27,2). In this last Callistratus fragment, the quotation is taken from 'another chapter of the instructions', alio quoque capite mandatorum. This implies that more fragments were taken from a 'chapter'. Callistratus is not the only one who speaks of chapters when referring to the Instructions. Marcian and Ulpian also mention capita mandatorum. ${ }^{19}$ The mentioning of chapters is a sign of the existence of a liber mandatorum. Such a 'Book of Instructions' probably existed

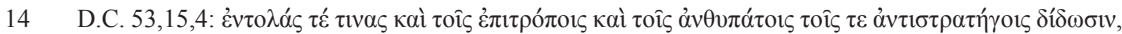

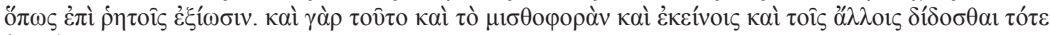
$\dot{\varepsilon} v o \mu i ́ \sigma \theta \eta$. The Emperor gives certain instructions to the procurators, the proconsuls, and the propraetors in order that they may proceed to their place of office on fixed conditions. Both this practice and the paying of salary to them and to the other employees of the government became customary at this period.

15 CIL III 7086; D. 37,14,7,1: Mandatis imperatorum cavetur ...

16 Most cited are Marcianus: D. 34,9,2,1; D. 47,11,6pr.; D. 47,22,1pr.; D. 47,22,3pr.-1; D. 48,3,6,1; D. 48,13,4,2; D. 48,13,5,3; D. 48,17,1.4; D. 48,21,3,7; Ulpianus: D. 1,16,6,3; D. 1,17,1; D. 24,1,3,1; D. 25,2,17pr.; D. 29,1,1pr.; D. 32,1,4; D. 47,11,6pr.; Coll. 11,7,4; Callistratus: D. 1,18,19; D. 48,19,27,1; D. $48,19,27,2$; D. $48,19,35$; D. 50,10,7,1. Furthermore Paulus: D. 1,18,3; D. 23,2,65pr.; Modestinus: D. $37,14,7,1$; D. $48,17,5$ pr.; Macer: D. 49,5,6: Papinianus: D. $18,7,5$.

17 From the time of Antoninus Pius: Venuleius Saturninus (D. 48,3,10; D. 48,19,15); from the time of Diocletian: Arcadius Charisius (D. 22,5,25). Cf Dell'Oro, Mandata e litterae (note 10 above), 62; Marotta, Mandata principum (note 10 above), 126 note 4 .

18 Cavetur: D. 22,5,25; D. 37,14,7,1; D. 47,11,6pr.; D. 48,3,10; D. 48,13,5,3; D. 48,17,5pr.; D. 48,19,35; D. $48,19,15$ (cautum est); D. 48,19,27,1-2; D. 48,21,3,7; D. 49,5,6; D. 50,10,7,1; continetur: D. 1,16,6,3; D. 1,17,1; D. 1,18,19; Coll. 11,7,4.

19 D. 48,3,6,1: Sed et caput madatorum extat... D. 29,1,1: Caput ex mandatis:...; Fron. Aq. 110-111: ..., ex capite mandatorum manifestum erit ...; cf. again the inscription from Pergamon (CIL III 7086)

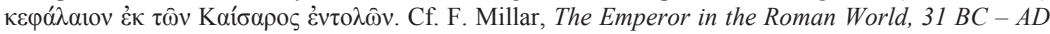
337, London 1977, 316ff. 


\section{CHANGING STATUS OF THE MANDATA PRINCIPIS}

in the time of the Severi. A direct indication of its existence can be found in the work Pro Lapsu inter Salutandum by Lucian of Samosate (AD 175) who speaks of a liber mandatorum:

Why, in that 'Book of Instructions' which you all receive from the Emperor, is not the first recommendation to take care of your health? Quite rightly; that is the condition preceding efficiency. Moreover, if I know any Latin, you yourselves, in returning a salutation, constantly use the equivalent of Health. ${ }^{20}$

On the basis of the existence of a 'Book of Instructions', the next question is whether this Book was the same for every provincial administrator or whether it was personally adapted to the particular official leaving the capital. In other words, was the liber mandatorum an established 'Code of Instructions' or did every departing governor receive a personal set of legal rules and moral precepts? It seems obvious to me that the latter was the case. ${ }^{21}$ In the first place the provinces differed from each other. Each province had its own habits and customary practices dear to the inhabitants. For example, it was customary for the proconsul of the province of Asia to arrive by sea and visit Ephesus before any other city. The prefect of Egypt did not divest himself of his imperium until his successor had actually entered Alexandria, even though the latter had already arrived in the province. ${ }^{22}$ Pliny the Younger was sent to Bithynia with instructions from Emperor Trajan for the particular purpose of correcting those many abuses which appeared in need of reform. ${ }^{23} \mathrm{He}$ had to make a detour in order to arrive first in the city of Prusa, as was the custom. ${ }^{24} \mathrm{He}$ writes that his colleague Gavius Bassus, prefect of the Pontic frontiers (Pontica ora), had not received the number of soldiers the Emperor had promised him in his mandata for this region. ${ }^{25}$ If the Roman official Frontinus had indeed received mandata, they certainly would have differed from

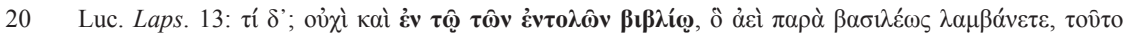

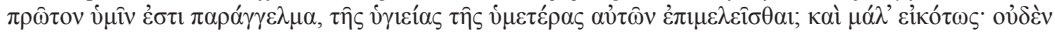

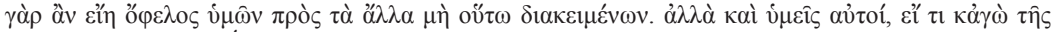

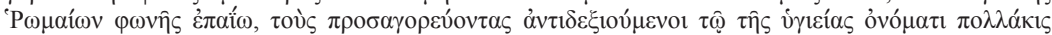
$\grave{\alpha} \mu \varepsilon^{\prime} \beta \varepsilon \sigma \theta \varepsilon$. See also Marotta, Mandata principum (note 10 above), $7 \mathrm{ff}$.

21 Cf. Dell'Oro, Mandata e Litterae (note 10 above), $73 \mathrm{ff}$.

22 D. $1,17,1$.

23 Plin. Ep. Tra. 10,32

24 Plin. Ep. Tra. 10,17a

25 Plin. Ep. Tra. 10,21. In Ep. 10,22, Trajan writes: Et mihi scripsit Gavius Bassus non sufficere sibi eum militum numerum, qui ut daretur illi, mandatis meis complexus sum. 
the rest. ${ }^{26}$ Not all the rules would have differed from each other, however: many instructions would have been identical and formed part of an established nucleus of the corpus mandatorum. Among the rules were certainly that a governor was not allowed to accept gifts ${ }^{27}$ or to donate large sums of public money, ${ }^{28}$ to marry a woman from his province, ${ }^{29}$ and that the governor was obliged to maintain a proper distance between himself and the inhabitants, ${ }^{30}$ to punish criminals according to their crime, ${ }^{31}$ etc. In sending criminal suspects deserving capital punishment to the provincial governor, Sempronius Caelianus undoubtedly acted in concordance with general instructions. ${ }^{32}$ All in all, the liber mandatorum takes the form of a book with permanent and interchangeable parts.

A second reason in favour of the existence of varying libri mandatorum can be derived from the first sentence of Novel 17 (16 April 535). Novel 17 begins with a Latin introduction directed at the quaestor sacri palatii Tribonian and gives some historical particulars. The first sentence says:

Your Sublime Highness is fully aware of how much the legislators have, each in his own volume, written on the Instructions of the Emperors in the ancient books which enclose the laws of the Roman name. ${ }^{33}$

From the fact that each Emperor wrote about the mandata in his own volume, it is no great step to see the Instructions as being constantly renewed, adapted and revised.

A third argument against an uniform codification of the Instructions is the total absence of any form of publication. ${ }^{34}$ No trace exists of the characteristics of a law - edict or

26 Frontinus (35-103) was curator aquarum in the capital. Finkelstein, 'Mandata principum' (note 10 above), 154 reserves the Instructions exclusively for the provincial magistrates. He thinks an error has been made. But the fact remains that we have Frontinus quoting from a caput mandatorum especially dealing with aquaducts.

27 D. $1,16,6,3$.

28 Plin. Ep. Tra. 10,110: ..., utebaturque mandatis tuis, quibus eius modi donationes vetantur; Ep. 10,111: Sicut largitiones ex publico fieri mandata prohibent, etc.

29 D. $24,1,3,1$.

30 D. $1,18,19 \mathrm{pr}$.

31 D. $1,18,3$.

32 Plin. Ep. Tra. 10,30: Secundum mandata mea fecit Sempronius Caelianus mittendo ad te eos, de quibus cognosci oportebit, an capitale supplicium meruisse videantur.

33 Nov. 17 pr. (SK 117/15-18): Ex libris antiquis, qui iura nominis Romani continebant, non ignorat sua sublimitas, quanta de mandatis principum legum latores in suo quoque volumine conscripserunt.

34 Cf. Marotta, Mandata principum (note 10 above), 16: 'Della pubblicazione integrale del liber mandatorum, durante il principato, non si ha alcuna prova' 


\section{CHANGING STATUS OF THE MANDATA PRINCIPIS}

rescript - such as the names of the Emperor(s), date and place of issue. No order or injunction is known to publish the mandata in the way the rescripts and imperial edicts had to be

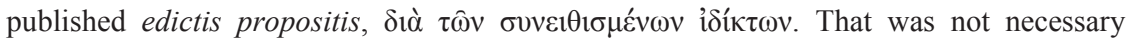
because the Instructions contained legal and moral precepts directed not to the citizens but to the magistrates. The citizens did not know exactly what the mandata comprised unless the magistrate indicated in his edict that he had acted secundum mandata principis. What we know from the jurisprudential texts of the Digest are the words and rules of some capita mandatorum, but these rules derive their legal validity not from being issued as mandata but from being provincial edicts by the magistrate.

It is by these provincial edicts and not by the imperial Instructions that the provincial citizens were governed. Only indirectly was the influence of the Instructions noticeable. ${ }^{35}$ The Instructions indicate the subject matter on which the magistrate has to take legal action, but the citizens obey the edicts of the magistrate, not the mandata principis. In other words, the magistratuum edicta were inspired and sometimes necessitated by the mandata, but the legal power was derived fom the imperium of the magistrate, not from the imperium of the Emperor. Through his imperial edicts, his sentences (decreta) and his rescripts, the Emperor was the lawgiver of the people, through his mandata he was the Instructor of the (provincial) magistrates. This is the reason why the mandata principum are not enumerated as imperial legal sources. After all, we have seen that neither Gaius nor Ulpian nor Justinian regarded the mandata principis as constitutiones. They have an independent legal position apart from the constitutions and senatusconsulta. And indeed, the jurisconsult Marcian writes in his second book on public law:

Unlawful associations are dissolved by mandata, constitutions and decrees of the senate ... 1. All in all unless an association or other such body be formed with the authority of a senatorial decree or of the Emperor, it is created in contravention of the senatus consulta, mandata and constitutions. ${ }^{36}$

35 Cf. Dell'Oro, Mandata e Litterae (note 10 above), 70: 'I giuristi romani non li (mandata) considerano mai fonti di diritto, contrastando a tale inclusione la loro derivazione da altre fonti e la loro destinazione solo indiretta al corpo sociale'. R. Orestano disagrees with Dell'Oro in his review in IURA XII (1961), 451-457, especially 453.

36 D. 47,22,3pr.: Marcianus libro secundo iudiciorum publicorum. Collegia si qua fuerint illicita, mandatis et constitutionibus et senatusconsultis dissolvuntur: ... I. In summa autem, nisi ex senatus consulti auctoritate vel Caesaris collegium vel quodcumque tale corpus coïerit, contra senatus consultum et mandata et constitutiones collegium celebrat. Cf. D. 48,13,4,2: Mandatis autem cavetur ... et sic constitutionibus cavetur, ... D. 47,11,6pr.: ... tam mandatis quam constitutionibus. 
In the second sentence of Marcian's text we read that associations were permitted by the authority of the senate and of Caesar only, not by mandata principis. If a provincial governor decided to dissolve an association, he did so by issuing a provincial edict, based on his imperium. Possibly and probably, the imperial Instructions may have influenced or even prescibed the making of this edict, but the mandata were not the legal foundation for the dissolution of the unlawful associations. It now becomes clear that the magistratuum edicta were enumerated as one of the legal sources and the mandata principum were not. ${ }^{37}$ It is also clear that there is an essential link between magistratuum edicta and mandata principum. The finest example of this link is the famous edict by Pliny forbidding the assemblies of the Christians:

Having done this, it was their custom to separate, and then reassemble, to eat in common a harmless meal. From this custom, however, they desisted after the publication of my edict, by which, according to your Instructions, I forbade the meeting of any assemblies. ${ }^{38}$

Another example is Pliny's question to Trajan about some people who had been banished from the province for three years by a judgement of the proconsul Servilius Calvus. However, this decretum was revoked by an edict issued by the same Calvus. Pliny asked the Emperor to tell him what to do, for the Instructions were silent on this particular point. They contained an order not to restore any person who had been sentenced to banishment by another magistrate, but gave no directions with respect to those who had been banished and restored by the same magistrate. Pliny asked to be informed and included in his letter the sentence of banishment and the edict of revocation. ${ }^{39}$

Frequently it was the other way around, in the sense that precepts, taken from rescripts and provincial edicts, were inserted into the mandata ${ }^{40}$ An example of a rescript which was incorporated into the Instructions is the law that no one can be imprisoned for life. It was ordained by Hadrian in a rescript and found its way into the Instructions:

37 Inst. 1,2,3: Scriptum ius est lex, plebi scita, senatus consulta, prinipum placita, magistratuum edicta, responsa prudentium. Gaius 1,2 speaks of edicta eorum, qui ius edicendi habent. As examples he mentions the praetor and the aedilis curulis (in 1,6), but qui ius edicendi habent also includes the governors of the imperial provinces (legati Augusti pro praetore) and the senatorial provinces (proconsules).

38 Plin. Ep. Tra. 10,96,7: ... Quibus peractis morem sibi discedendi fuisse rursusque coeundi ad capiendum cibum, promiscuum tamen et innoxium; quod ipsum facere desisse post edictum meum, quo secundum mandata tua hetaerias esse vetueram.

39 Plin. Ep. Tra. 10,56. The Emperor answered that he would personally ask Calvus for the reasons behind these proceedings: 10,57 .

40 Cf. D. 47,12,3,4: ...edicto divi Severi continetur, quo mandatur, .... 


\title{
CHANGING STATUS OF THE MANDATA PRINCIPIS
}

In the mandata given by the Emperors to provincial governors, it is provided that no one is to be condemned to permanent imprisonment; the deified Hadrian also wrote a rescript to this effect. ${ }^{41}$

An example of a senatusconsult being inserted into the mandata is the law forbidding someone to eradicate the names of previous benefactors on a building which he has adorned:

\begin{abstract}
If someone undertook to decorate a building erected by someone else with marble or to do it in some other way according to the will of the people, with his name to be included in the inscription and the inscriptions to remain of the earlier benefactors who had erected the building, the senate decreed that the project should go ahead. And if private individuals add some money from their own resources for buildings which are erected from public funds, it is laid down in the same mandata that they should organize the inscription in such a way as to record the sum which they had contributed for the building. ${ }^{42}$
\end{abstract}

An example of a provincial edict that was inserted into the Instructions is an edict issued by Antoninus Pius in his capacity as proconsul of Asia, ordaining that police officers (irenarchae, lit.: peace-officers) interrogate the banditti and send a sealed report to the court of the magistrate. ${ }^{43}$ Marcian in his second book on public law informs us that this edict of Pius is part of the mandata as a special caput. ${ }^{44}$ Whether Pius himself inserted his edict or another Emperor is not clear, but the information proves that each Emperor composed a volumen of

41 D. 48,19,35: Mandatis principalibus, quae praesidibus dantur, cavetur, ne quis perpetuis vinculis damnetur: idque etiam divus Hadrianus rescripsit.

42 D. 50,10,7,1: Si quis opus ab alio factum adornare marmoribus vel alio quo modo ex voluntate populi facturum se pollicitus sit, nominis proprii titulo scribendo: manentibus priorum titulis, qui ea opera fecissent, id fieri debere senatus censuit. quod si privati in opera, quae publica pecunia fiant, aliquam de suo adiecerint summam, ita titulo inscriptionis uti eos debere isdem mandatis cavetur, ut quantam summam contulerint in id opus, inscribant.

43 D. 48,3,6,1: Marcianus libro secundo de iudiciis publicis. Sed et caput mandatorum exstat, quod divus Pius, cum provinciae Asiae praeerat, sub edicto proposuit, ut irenarchae, cum adprehenderint latrones, interrogent eos de sociis et receptatoribus et interrogationes litteris inclusas atque obsignatas ad cognitionem magistratus mittant. (...). The Basilica speak of magistrates in the plural; cf. B. 60,35,6

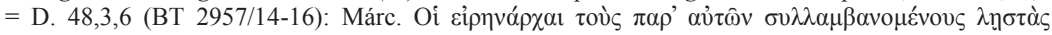

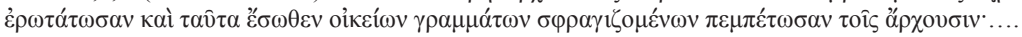

44 A Basilica scholion pertaining to the passage in the above note mentions imperial mandates; cf. sch.

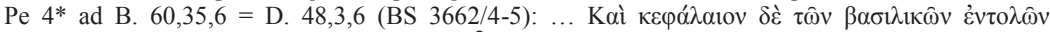

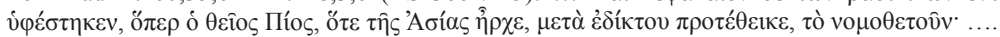


Instructions by adding and subtracting passages. Another caput of the mandata makes this even clearer. The chapter is about soldiers, permitting them to draw up a testament without the usual formalities, in any way they wish:

The deified Julius Caesar was in fact the first to concede to soldiers the unrestricted legal capacity to draw up a testament; but that concession was temporary. However, later the deified Titus first gave it (this capacity); after this Domitian; thereafter, the deified Nerva conferred the fullest indulgence on soldiers; and Trajan followed this, and thenceforth such a chapter came to be inserted in the mandata principis. A chapter from the mandata: 'As it has been submitted to my notice that wills left by our fellow soldiers, which could be open to dispute if regard were had to the diligent observance of the laws, are repeatedly submitted; following the openness of my heart toward those excellent and most faithful fellow soldiers, I thought that provision should be made for their inexperience, so that whatever the way in which they made their wills, their wishes should be confirmed. Therefore, let them draw up their wills in any way they wish, let them make them in any way they can, and let the bare wishes of the testator suffice to settle the distribution of their property'. ${ }^{45}$

The mandata in this text were nothing new, because Nerva had already given the soldiers complete freedom in drawing up their last wills. Trajan then adopted it, after which it became a chapter in the Instructions. The inclusion in the mandata did not give the rule legal force. If the provincial rulers wished to make a law in a special case they had to issue an edict.

No mention is made of the written form being compulsory for the Instructions, although it was the usual form in which they were clothed. It is possible that the governor sometimes received oral Instructions at the moment of his departure, caused by some urgent occasion primus quidem divus Iulius Caesar concessit: sed ea concessio temporalis erat. postea vero primus divus Titus dedit: post hoc Domitianus: postea divus Nerva plenissimam indulgentiam in milites contulit: eamque Traianus secutus est et exinde mandatis inseri coepit caput tale. Caput ex mandatis: 'Cum in notitiam meam prolatum sit subinde testamenta a commilitonibus relicta proferri, quae possint in controversiam deduci, si ad diligentiam legum revocentur et observantiam: secutus animi mei integritudinem erga optimos fidelissimosque commilitones simplicitati eorum consulendum existimavi, ut quoquomodo testati fuissent, rata esset eorum voluntas. faciant igitur testamenta quo modo volent, faciant quo modo poterint sufficiatque ad bonorum suorum divisionem faciendam nuda voluntas testatoris'. 


\section{CHANGING STATUS OF THE MANDATA PRINCIPIS}

or political incident. ${ }^{46}$ Perhaps in 215 Caracalla gave oral mandata to Aurelius Antinous, the successor to the executed prefect of Egypt Heraclitus. Heraclitus was punished for his incompetence in suppressing an insurgency in Alexandria. Caracalla, who was at the time in Egypt, reacted on the spot and instructed Antinous to banish from the city all the $\xi$ ćvol, that is to say all the Egyptian farmers who had fled their region in order to escape the fiscus. ${ }^{47}$

In summing up what we know about the mandata principis during the Principate, we come to the conclusion that the princeps Augustus and his successors conferred Instructions, mandata, upon the provincial governors - legati Augusti pro praetore and later also procon$s u l s^{48}$ - before they set out for their provinces. The mandata were put in writing but could be delivered orally and secretly in special circumstances. Over the course of time a corpus mandatorum emerged, called by Lucianus a liber mandatorum. This corpus was revised and re-edited by each Emperor and therefore consisted of permanent and interchangeable parts. Special officers took care of the mandata and stored them in the archives. ${ }^{49}$

The contents of the Instructions were a mixture of moral and legal precepts and could be taken from rescripts, provincial edicts, or decrees of the senate.

The mandata principum were not published in the usual way like rescripts or imperial edicts; they did not contain the name of the issuing Emperor(s), nor the date or the place of issue. The Instructions were known to the citizens in the form of edicts by the provincial magistrates. This is why there is a link between magistratuum edicta and mandata principum, and why the edicta magistratuum are enumerated in the Institutes of Gaius, Ulpian and Justinian as legal sources and the mandata principis are not, not even as a variant of the imperial constitutions.

In his commentary on the Theodosian Code, Gothofredus distinguishes between the ordinary mandata and the extraordinary ones; cf. Codex Theodosianus cum perpetuis commentariis Iacobi Gothofredi... Editio nova in VI tomos digesta, Tomus I, Lipsiae 1736, 29 (Commentarius ad CTh. 1,3,1): ‘...: nempe extraordinarium, quod videlicet necessitate aliqua vel occasione publica extra ordinem urgente de Palatio ab Imperatore in provincias missis vel Legatis dabantur, ...'.

47 P. Giss. 40 (= inv. 15), col. II, 11. 16-30, in O. Eger / E. Kornemann / P.M. Meyer (Hrgb.), Griechische Papyri im Museum des oberhessischen Geschichtsvereins zu Giessen, Leipzig-Berlin 1910-1912, Heft 2 (1910), 45. See extensively Coriat, Le prince législateur (note 11 above), 484-485 and 556.

48 Legati governed the imperial provinces, proconsuls the senatorial provinces. For the difference between the two: D.C. $53,13-15$.

49 CIL VI 8814: T. Fl(avius) Jason Aug(usti) lib(ertus) custos a mand(atis) (Traianus); CIL VI 8813: Aurelius D[ionisy]sus custos offici a m[and(atis)] (Marcus Aurelius); CIL III 536 = ILS 1575: Theoprepen $|\ldots|$ proc(uratorem) a mandatis, ... $\mid$. (Alexander Severus); cf. Marotta, Mandata principum (note 10 above), 26-27. 
After the Principate (the last text is from Arcadius Charisius from the age of Diocletian) we do not hear much about the mandata. Nevertheless, they are given a special title in the Theodosian and Justinian Codes - not in the Digest -, but each of these titles consists of just one text: in the Theodosian Code CTh. 1,3,1 (= C. 1,15,1), in the Justinian Code C. $1,15,2 .{ }^{50}$ Although the substance of the text in the Theodosian Code is about mandata, the legal form has all the characteristics of a rescript. It is a letter sent by the Emperors Gratian, Valentinian and Theodosius and directed to Eusignius, proconsul of Africa. ${ }^{51}$ It was issued on the sixteenth day before the Kalends of July (16 June) and accepted on the day before the Kalends of August (31 July) in the year of the consuls Merobaudus (for the second time) and Saturninus (383); the place of issue is Verona. The rescript deals with a special problem, unknown in the texts of the Principate. It is a warning to the provincial praesides to believe no one asserting that he has received secret (oral) Instructions from the Emperor, whatever his rank may be, unless he proves his statement by documentary evidence, i.e. by imperial letters.

The text from the Justinian Code (C. 1,15,2) has come down to us through the Basilica.$^{52}$ The Latin text is lost, so it seems..$^{53}$ The law deals with the same problem. The Emperors Justin and Justinian are warning the provincial governors not to call on oral Instructions in their summonses and judgements. To be valid, every oral Instruction on matters of procedure must be made public by the quaestor sacri palatii and his referendaries in an

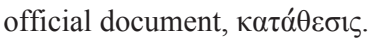

Up to this point, the mandata had never appeared in the inscription of a constitution. Only once were they sent in the legal form of a rescript with the names of the Emperors in the inscription and a date and place of issue. The inscriptio of C. 1,50,2 (followed by the remainder of the constitution) says:

Mandata impp. Theodosii et Valentiniani AA. missa ad Antiochum pp. per referendarium, quae sic habent [Instructions of the Emperors Theodosius and Valentinian Augusti sent to Antiochus, praetorian prefect, by referendarius, which are as follows]: Informed by the suggestion of Your Magnificence, Our Eternity has deemed it proper to grant authority to those

50 In the Justinian Code, the title C. 1,15 consists of two texts, but one is identical with the text from the Theodosian Code (CTh.1,3,1).

51 The Justinian Code wrongly styles him praefectus praetorio.

52 B. $2,6,19=$ C. $1,15,2($ BT $77 / 15-26)$.

53 The inscriptio is restituted on the basis of Nov. 124 c. 4 . The subscriptio of the constitution, viz. $d$. vi.

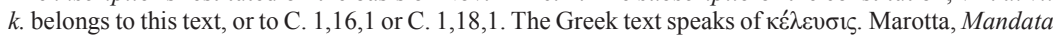
principum (note 10 above), 77 draws a distinction between imperial commandments, iussa, and general precepts, mandata. 


\section{CHANGING STATUS OF THE MANDATA PRINCIPIS}

who by the order of the Emperor or by that of Your Court are recognized as substitutes for the provincial governors, to appoint guardians or curators for those persons demanding them, to make decrees granting the alienation of estates of minors and suchlike persons and town councillors, also to grant legal emancipations and to do all other things pertaining to the jurisdiction of the provincial governor; in accordance with the decree of Your Highness they shall have permission to perform all acts of this kind above mentioned. Issued in Constantinople on the day before the Ides of October (14 October) during the consulship of Hierius and Ardabur (427)..$^{54}$

It is not the content of this law that is important, but the form in which these Instructions are clothed. I suspect that something went wrong during the editing process. I think it was meant to be an ordinary rescript. The first words of the law seem to support this opinion: suggerente magnificentia vestra. From these words it appears that the precepts are being made on the basis of a report (suggestion) by the praetorian prefect Antiochus. We know that many rescripts are issued after the consultations, questions and suggestions of high magistrates. ${ }^{55}$ The mandata of 427 issued in the form of a constitution are unique and extra ordinem.

\section{Novel 17}

The Emperor Justinian fundamentally changed the status of the mandata. He fitted the Instructions into the frame of the constitutions and thus gave them a legal foundation. After finishing his great legal project in 534 by issuing the revised Code, the Emperor proclaimed a year later, on 16 April 535, a Novel reviving an old custom and restoring the mandata.

54 C.1,50,2: Suggerente magnificentia vestra docta imperialis aeternitas debere eos, qui praeceptione principali seu vestrae sedis amplissimae tueri locum rectorum provinciarum noscuntur, auctoritatem habere tutores seu curatores petentibus dare, decretum etiam interponere ad alienandas minorum similiumque eis personarum seu curalium facultates, emancipationes quoque legibus celebrare et omnia quae ad iurisdictionem rectoris provinciae pertinent actitare, praecipere dignata est pro dispositione vestrae celsitudinis praefatas huiusmodi sollicitudines peragendi habere licentiam. D. prid.id. Oct. Constantinopoli Hierio et Ardabure conss.

55 C. 1,14,2: Quae ex relationibus vel suggestionibus iudicantium per consultationem in commune florentissimorum sacri nostri palatii procerum auditorium...Cf. C. 7,61 and C. 7,62, especially C. 7,62,34. See Lokin, 'The first constitution of the Codex Justinianus' (note 7 above), 369-372. 
This Nov. 17 has come down to us in Greek, although a Latin version existed. ${ }^{56}$ This we can derive from the Latin preface, directed at the quaestor Tribonian. In this preface the Emperor tells us the mandata are meant for the middle and lower ranks of the provincial officials, qui minores vel medias administrationes gerunt. The Emperor, or rather Tribonian, has composed a liber mandatorum, which will be handed over to the governors together with the documents, codicilli, of their appointment, before they set out for their provinces.

One gets the impression that this liber was drawn up once and for all and was meant to last forever, in perpetuum. It had to be transcribed into the Books of the Laws, in libris legum transcribere, by the quaestor and stored away in the imperial achives, in sacro laterculo. ${ }^{57}$ In this way everyone could consult the liber mandatorum as a sort of administrative Code and could hold the magistrate responsible for his government. As a consequence of this fixation, the personal and individual character of the mandata was lost.

Substantially, Nov. 17 is connected with Nov. 8 prohibiting the purchase of offices, which was issued at the same time as Nov. 17. ${ }^{8}$ The purpose of both Novels was to fight against

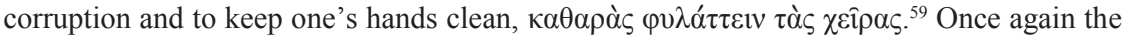
provincial magistrate is warned not to trust oral Instructions. Even written Instructions he must check and double-check. If someone claims to have received an Instruction to build an aquaduct, a road, a bridge, a wall, or to pull down houses in a public place, even if he can

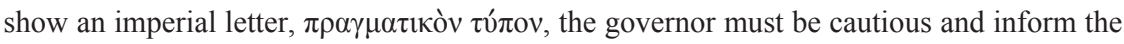

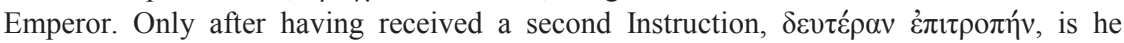
secure. ${ }^{60}$

Many Instructions taken from the ancient mandata appear in the Novel. It is, however, not the pupose of this contribution to repeat the substance of Nov. 17, but to consider the form in which it is shaped. ${ }^{61}$ The mandata undoubtedly had legal force. They were Roman

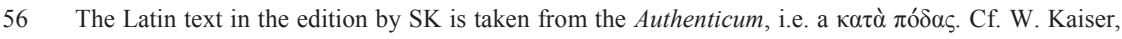
'Studien zu den Novellen Justinians. I: Die Zweisprachigkeit reichsweiter Novellen unter Justinian', SZ 129 (2012), 392-474 (434-437). The title to the Latin text, added later, reads De mandatis principum (SK 117/12), to the Greek text Mandata principis.

57 For these libri legum, cf. G. Lanata, Legislazione e natura nelle Novelle giustinianee, (Storia del pensiero giuridico, 7), Napoli 1984, 42 note 71.

58 Nov. 8 is dated 15 April 535 and so is the list of offices which is appended to it; the edict meant for the bishops is dated 17 April 535; on Nov. 8, cf. in particular R. Bonini, Ricerche sulla legislazione giustinianea dell' anno 535. Nov. Iustiniani 8: venalità delle cariche e riforme dell' amministrazione periferica, Bologna $1980^{2}$.

59 For the 'mani pulite', see Puliatti, 'La "carta dei doveri"' (note 10 above), 256-257.

60 Nov.17, c. 4.

61 When considering the contents of the Instructions, we can see a minor change from neutral rules of conduct to moral and legal warnings against evil and abuse. Many Instructions, especially during the 


\section{CHANGING STATUS OF THE MANDATA PRINCIPIS}

laws every citizen could invoke. They were a species of the constitutions for two reasons. In the first place they were formally issued as a novella constitutio. The suggestion that only the Latin preface was a constitution and that the Greek text was nothing more than an informative addition, subter adnexus, must be rejected. The Greek part is provided with a proper subscription (date and place of issue) and an inscription in which the Trinity is invoked and all the titles of the Emperor are formally enumerated ${ }^{62}$ For obvious reasons the names of the governors, being unknown, are left out. The second reason in favour of the mandata being a constitution is the way in which they were published. Perhaps to compensate for the earlier absence of publicity, the Emperor prescribed a somewhat exaggerated

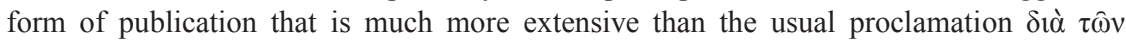

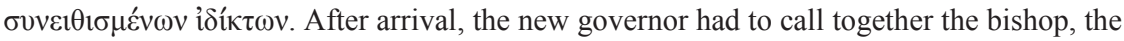
clergy and the notables of the provincial metropolis and make the Instructions known to all, before storing them away in the local archives. Copies had to be made free of charge and sent to the cities in the province so that anyone could consult them. ${ }^{63}$

\section{Conclusion}

To conclude, we can see that the status of the mandata changed due to their reception into the novellae constitutiones of Justinian. They became a legal source.

Was Nov. 17 effective? That is a matter of some doubt. In 535 and 536 the liber mandatorum was issued to the provincial magistrates, in 535 to the praetor of Pisidia (Nov. 24), the praetor of Lycaonia (Nov. 25), the praetor of Thracia (Nov. 26), the count (comes) of Isauria (Nov. 27), the moderator of Helenopontus (Nov. 28), and the praetor of Paphlagonia (Nov. 29); in 536 to the proconsul of Cappadocia (Nov. 30) and the moderator of Arabia (Nov. 102). In each Novel the Emperor used the original expression in Greek characters:

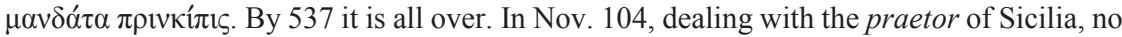
mention is made of the mandata. All in all, the commentary by the greatest authority on the Novels is perhaps nearest to the truth:

Principate, were not much more than practical rules regulating an official's conduct and the organisation of his administration. For this reason, Finkelstein draws a distinction between technical and nontechnical mandata; Finkelstein, 'Mandata principum' (note 10 above), 152. A recent survey of the contents of Nov. 17 is given by Puliatti, 'La "carta dei doveri"' (note 10 above).

62 Some Novels have the same complete inscription: Nov. 43 (537), Nov. 86 (539), Nov. 134 (556), Nov. 137 (565), Nov. 139 (539; invocation, no titles), Nov. 150 (563; Latin), Typos pragmatikos (=Ed. VII, 542), Appendix 2 and 3 (541 and 542; Latin, no invocation, titles), Appendix 8 (558; Latin).

63 Nov. 17, c. 16; cf. Lanata, Legislazione e natura (note 57 above), 151 


\section{LOKIN}

Il se peut que dans les premières années suivantes, on ait de temps en temps remis un exemplaire du texte aux magistrats nouvellement installés; pourtant, je ne crois pas que l'usage fût vraiment rétabli: pour cela, il aurait fallu moderniser et mettre à jour régulièrement le texte des mandata, comme on le faisait à l'époque du Haut-Empire. ${ }^{64}$

64 Cf. N. van der Wal, Manuale Novellarum Justiniani. Aperçu systématique du contenu des Novelles de Justinien, Groningen $1998^{2}, 15$ note 16. 